\title{
PENGENALAN BAHASA DELPHI
}

\author{
Lia Aulina \\ 165100113, KDV \\ Fakultas Komputer \\ liaaulina.student@umitra.ac.id
}

\begin{abstract}
Borland Delphi 7 adalah bahasa pemrograman yang bekerja pada lingkup sistem operasi windows, dan merupakan salah satu program yang berorientasi object ( OOP ). kemampuanya dapat dipakai untuk merancang program aplikasi yang berpenampilan seperti program aplikasi lainya yang berbasis Windows. Kemampuan Borland Delphi 7 secara umum adalah menyediakan komponen komponen yang memungkinkan anda membuat program aplikasi yang sesuai dengan tampilan dan cara kerja windows, diperkuat dengan bahasa pemrograman tersetruktur yang sangat handal, yaitu bahasa pemrograman Object Pascal yang sangat terkenal. Khusus untuk pemrograman database Borland Delphi 7 menyediakan fasilitas object yang sangat kuat dan lengkap.
\end{abstract}

Kata Kunci : pengenalan bahasa delphi. 


\section{A. INTRODUCTION}

Mengenal Sepintas Borland Delphi 7 Borland Delphi 7 adalah bahasa pemrograman yang bekerja pada lingkup sistem operasi windows, dan merupakan salah satu program yang berorientasi object ( OOP ). kemampuanya dapat dipakai untuk merancang program aplikasi yang berpenampilan seperti program aplikasi lainya yang berbasis Windows. Kemampuan Borland Delphi 7 secara umum adalah menyediakan komponen komponen yang memungkinkan anda membuat program aplikasi yang sesuai dengan tampilan dan cara kerja windows, diperkuat dengan bahasa pemrograman tersetruktur yang sangat handal, yaitu bahasa pemrograman Object Pascal yang sangat terkenal. Khusus untuk pemrograman database Borland Delphi 7 menyediakan fasilitas object yang sangat kuat dan lengkap. Selain menyediakn format database Paradoxs dab dBase Borland Delphi 7 juga menangani bebrbagai macam format database seperti: MS-Access, ODBC, SyBASE, Oracle dan lain lain.

\subsection{Memulai Program Borland}

Delphi7

Untuk memulai menjalankan Borland Delphi 7 lakukan langkah langkah sebagai berikut:

a. Klik Icon Start pada sistem operasi Windows (pastikan program Borland Delphi 7 sudah di install)

b. Tunjuk program, lalu pilih Borland Delphi 7 atau Delphi 7, kemudian akan muncul program Borland Delphi 7 yang sudah siap dipakai, seperti yang nampak pada gambar dibawah ini :

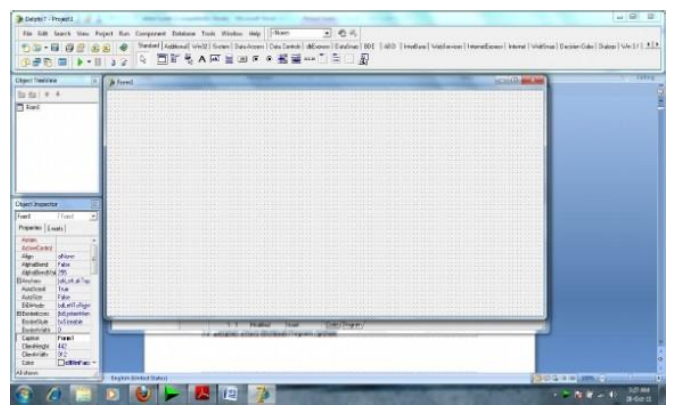

\subsection{Langkah Umum Membuat}

Program Aplikasi

Program berikut program yang sederhana brtujuan untuk memudahkan dalam memahami membuat program aplikasi Borland Delphi 7 . Langkah langkah umum untuk membuat program aplikasi dengan Borland Delphi 7 adalah sebagai berikut :

a. Gambar object dan tata letak kedalam jendela form menggunakan ikon ikon object dalam komponen palette.

b. Bila perlu, tentukan properti pada tiap komponen menggunakan lembar properties pada jendela Object Inspector

c. Tuliskan kode program untuk event pada object yang diinginkan. Event adalah suatu kejadian yang dirasakan object, misalnya tunjuk klik, atau kejadian lainya.

\subsubsection{Membuat Program Aplikasi Pertama} Sebagai contoh yang pertama kita membuat program program aplikasi pencatat waktu seperti yang nampak pada gambar berikut :

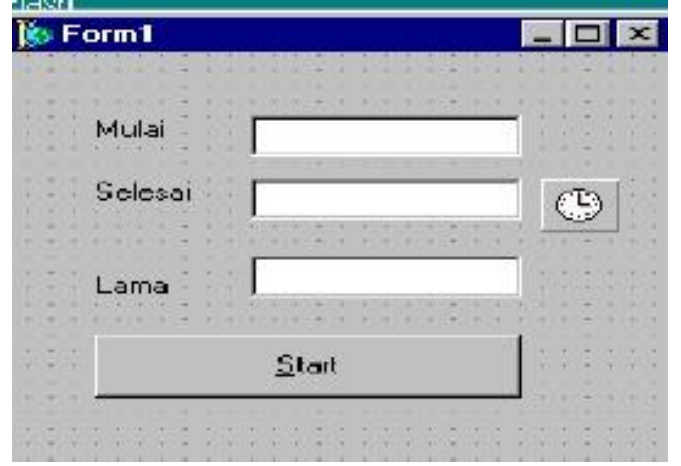


Untuk mebuat contoh program diatas, lakukan langkah langkah sebagai berikut : 1. klik ganda pada icon label yang terdapat pada tab standart dalam konponen Palette, sehingga muncul object yang bernama label1. 2. ubah properties caption-nya pada jendela object inspector menjadi Mulai, kemudian atur tata letaknya seperti pada gambar diatas. 3. lakukan cara yang sama untuk mendapatkan label Selesai dan Lama. 4. tambahkan object edit yang letaknya disebelah kanan label. Dan kosongkan properties Text-nya.

5. tambahkan oject button, letakkan dibawah object label dan edit seperti yang nampak pada gambar. Ubah properties captionya menjadi Start.

6. tambahkan object timer yang letaknya pada tab System dalam komponen palette. 7. tekan tombol F12 untuk menampilkan editor kode program, kemudian tuliskan kode programnya. Ingat Borland Delphi 7 sudah memberikan sebagian kode program anda tinggal melengkapinya saja. Untuk kembali ke design form tekan F12 lagi. Jadi tombol ini untuk menuju design Form dan kode program secara bolak balik. Atau dengan cara meng-kilk object yang akan diisi program.

8. setelah selesai, jalankan program diatas dengan memilih menu Run lalu pilih Run atau tekan tombol F9 atau klik Icon Run 9. Kode program dapat anda lihat seperti dibawah ini: Unit lat01; Interface Uses Windows, messages, SysUtils, Classes, Graphics, Controls, Forms, Dialogs, StdCtrls, ExtCtrls; Type Tform1 = class(Tform) Timer1:Ttimer; Edit1:TEdit; Edit2:Tedit; Edit3:Tedit; Label1:Tlabel; Label2:Tlabel Label3:Tlabe

Button1:Tbutton; Procedure FormCreate(Sender: Tobject); Procedure Button1Clik(Sender: Tobject); Procedure Timer1Timer(Sender: Tobject); Private \{ Private Declaration $\}$ public \{ Public
Declaration \} end; var Form1

:Tform1; Awal,akhir : tDateTime; Lama : Real; Implementation ( SR *.DFM ) procedure Tform1.FormCreate (Sender: Tobject); begin timer1.Interval:=1; end; procedure Tform1.Button1Click(Sender:

Tobject); begin if Button1.Capt

ion $={ }^{\text {ee }}$ Start ${ }^{\text {ee }}$ then

begin awal:=time;

edit1.text:=timetostr(time);

Button1.caption $={ }^{\text {ee }}$ Stop ${ }^{\text {;e }}$;

end

else if button 1.caption= $={ }^{e}$ Stop ${ }^{e e}$ then

Button 1.caption $=$ "Selesaiee

Else Aplication.terminate End;

Procedure Tform1.Timer1Timer(Sender:

Tobject); Var slama: String; Begin

If Button1.Caption="Stope Then

Begin Akhir:=time;

Edit2.text:TimeToStr(akhir); Lama:=(akhirawal)*100000; Str(lama:12:2,Slama);

Edit3.text:=slama; End; End; End. 1.3.2

Menyimpan Program Aplikasi Sebelum program dijalankan disarankan untuk disimpan dahulu. Untuk penyimpanan ada bebrapa cara dan pilihan. Untuk menghindari kesalahan biasakan untuk memilih

Save All

atau

Save project as

. Setelah anda pilih pilihan itu maka anda akan disuruh menyimpan sebanyak dua kali yaitu menyimpan form/unitnya dan menyimpan projectnya dari unit tersebut

1.3.3 Menutup Program Aplikasi Untuk menutup program aplikasi Borland Delphi 7 anada cukup memilih file kemudian pilih Close all , untuk keluat Klik File kemudian Exit atau tombol close yang terletak pada pojok kanan atas. 


\subsection{Beberapa Komponen Borland Delphi 7 \\ Untuk dapat menguasai pemrograman} Borland Delphi 7 dengan baik maka kita harus tau beberapa komponen yanga ada di Borland Delphi 7 dan memepelajarinya dengan baik, adapun komponen tersebut antara lain:

1.4.1 Project Project adalah sekumpulan form, unit dan beberapa hal lain artinya project adalah program itu sendiri. File project disimpan dengan akhiran .dpr, beberapa file yang diperlukan untuk poject adalah sebagai berikut:

a. File Unit (.pas) Dipakai untuk menyimpan program (kode program), unit ini berhubungan langsung dengan form, tapi kadangkala unit hanya berupa procedure dan function yang tidak berhubungan dengan form.

b. File Form (.dfm) Dipakai untuk menyimpan semua informasi mengenai form c. File project Option(.dfo) Dipakai untuk menyimpan semua setting option (pilihan) project.

d. File Resource(.res) Dipakai untuk menyimpan icon yang dipakai project. e. File Backup(. dp, . df, , pa) Dipakai untuk menyimpan file backup project, form dan unit.

\subsubsection{Form}

Form adalah suatu object yang dipakai sebagai tempat bekerja program aplikasi. Dalam satu project bisa dibuat lebih dari satua form. Setiap form mengadung unit. Unit dalam form dipakai untuk mengatur dan mengendalikan form, gambar form seperti nampak pada gambar dibawah ini :

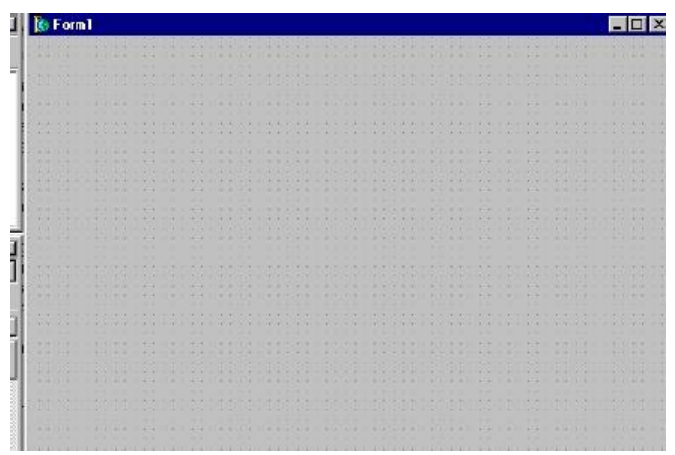

\subsubsection{Unit}

Unit adalah modul kode program, satu program mungkin memiliki lebih dari satu unit. Setiap kali kita membuat form maka otomatis Borland Delphi 7 memberikan unitnya juga. Ada juga unit yang terpisahkan dengan form yang berisi sekumpulan procedure dan fungsi. Manfaat penggunaan unit dalam program antara lain sebagai beriku a. Membagi program yang besar kedalam beberapa unit, sehingga kita dapat mengedit unit-unit tertentu saja. b. Membuat library (daftar pustaka) berupa procedure dan function sehingga memudahkan sharing antar program. c. Unit dapat dikompilasi terpisah dari program aplikasi, sehingga program aplikasi lain yang memerlukan unit serupa dapat menggunakanya tanpa harus menulis kembali kode program tersebut.

\subsubsection{Program Sebuah program secara umum} mempunyai struktur sebagai berikut :

a. Heading Program, yaitu bagian yang menunjuk nama program tersebut.

b. Pernyataan USES, yang berisi daftar unit yang dipakai program c. Blok deklarasi dan pernyataan, yaitu bagian yang berisi deklarasi dan pernyataan program yang dilaksanakan pada saat program dijalankan. Bagian ini harus diakhiri dengan penyataan End diikuti tanda titik. 
1.4.5 Properties Properties digunakan untuk menentukan setting suatu object. Suatu object biasanya mempunyai beberapa properti. Properties sendiri letaknya bersebelahan dengan event pada jendela Objeck Inspector. Gambar properties dapat dilihat pada gambar dibawah ini :

\begin{tabular}{|c|c|c|}
\hline \multicolumn{2}{|l|}{ Dbiect Insperctor } & $x$ \\
\hline Formt & TForm1 & $\square$ \\
\hline Properties & nt: 1 & \\
\hline ActiveCiontral & & 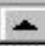 \\
\hline Align & alNone & \\
\hline AlphaBlend & False & \\
\hline AlphaBlendValt & 255 & \\
\hline$\boxplus$ Anchors & [akLeft,akTop] & \\
\hline Autoscrall & True & \\
\hline Autasize & False & \\
\hline BiDikode & budLeftT ofight & \\
\hline$\Phi$ Barderlcans & [biSystemlenu. & \\
\hline BorderStyle & bus Sizeable & \\
\hline Borderwidth & 0 & \\
\hline Caption & Form1 & 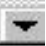 \\
\hline
\end{tabular}

1.4.6 Event Event adalah peristiwa atau kejadian yang diterima oleh suatu object misalkan klik, drag dan lain lain. Sebagai contoh dapat dilihat potongan kode program sebagai berikut :

procedure Tform1.Button1Click(Sender:

Tobject); begin

if Button1.Caption=" Start"e then

begin awal:=time;

edit1.text:=timetostr(time); $\mathrm{Bu}$

tton 1 .caption $={ }^{\text {ee }}$ Stop ${ }^{\text {ee }}$;

end

else if button1.caption=" Stop ${ }^{\text {ee }}$ then

Button1.caption $={ }^{\text {"SSelesai }}{ }^{\text {ee }}$

Else Aplication.terminate End; Program diatas menunjukan event Click pada object button1.

Beberapa pilihan event pada object button dapat dilihat pada gambar dibawah ini:

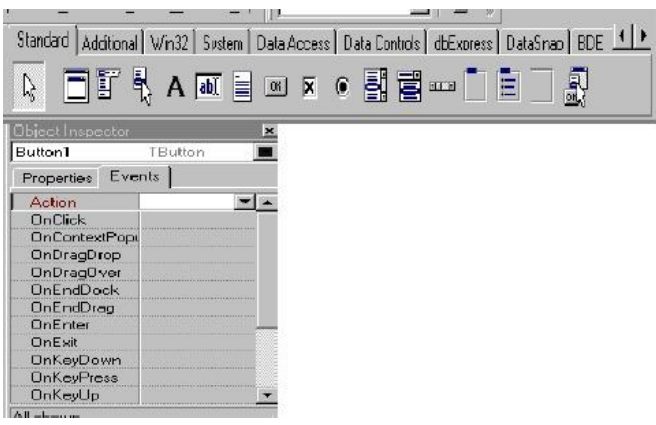

1.4.7 Komponent Palette Komponen palette adalah kumpulan object yang dipakai untuk mendesign program. Beberapa komponen palette anatara lain komponen standart, additional, win32, System dan lain lain yang berisi object yang berbeda beda sesuai dengan masing masing komponen tersebut Gambar komponen pallete dapat dilihat pada gambar dibawah ini :

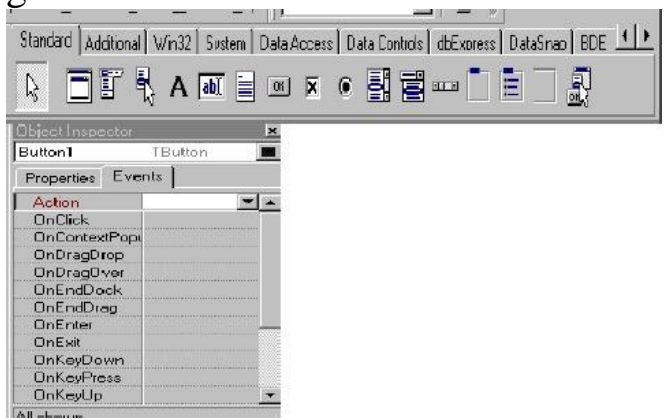

\subsection{Kegunaan Delphi}

1. Untuk membuat aplikasi windows 2. Untuk merancang aplikasi program berbasis grafis

3. Untuk membuat program berbasis jaringan (client/server)

4. Untuk merancang program .Net (berbasis internet)

1.6 Keunggulan Delphi

1. IDE ( I $n$ t e $g$ r a t e d

D e v e lop m e $n t$

E n v i r o n m e $n t$ ) atau 
lingkungan pengembangan aplikasi sendiri adalah satu dari beberapa keunggulan delphi, didalamnya terdapat menu

menu yang memudahkan kita untuk membuat suatu proyek program.

2. Proses Kompilasi cepat, pada saat aplikasi yang kita buat dijalankan pada Delphi, maka secara otomatis akan dibaca sebagai sebuah program, tanpa dijalankan terpisah.

3. Mudah digunakan, source kode delphi yang merupakan turunan dari pascal, sehingga tidak diperlukan suatu penyesuaian lagi.

4. Bersifat multi purphase, artinya bahasa pemograman Delphi dapat digunakan untuk mengembangkan berbagai keperluan pengembangan aplikasi.

\section{B. CONTENT} Study kasus:

Buatlah Program Nilai Akhir Mahasiswa dengan menggunakan Procedure IF..THEN..ELSE ,dengan ketentuan :

- Nilai Absen $=10 \%$

- Nilai Tugas $=15 \%$

- Nilai UTS $=25 \%$

- Nilai UAS $=50 \%$

^Saat pertama kali membuka

Delphi akan tampak tampilan yang berupa form yang mana form tersebut adalah area untuk bekerja. Lihat gambar dibawah ini.

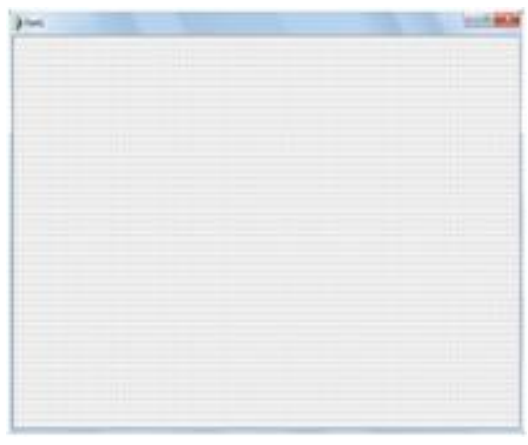

$\aleph$ Setelah memperhatikan komponenkomponen pallete maka anda dapat memberikan Label (berupa keterangan).edit(data yang akan diimput) dan Button merupakan bagian dari pemrosesan kode program agar program dapat berjalan (Run)

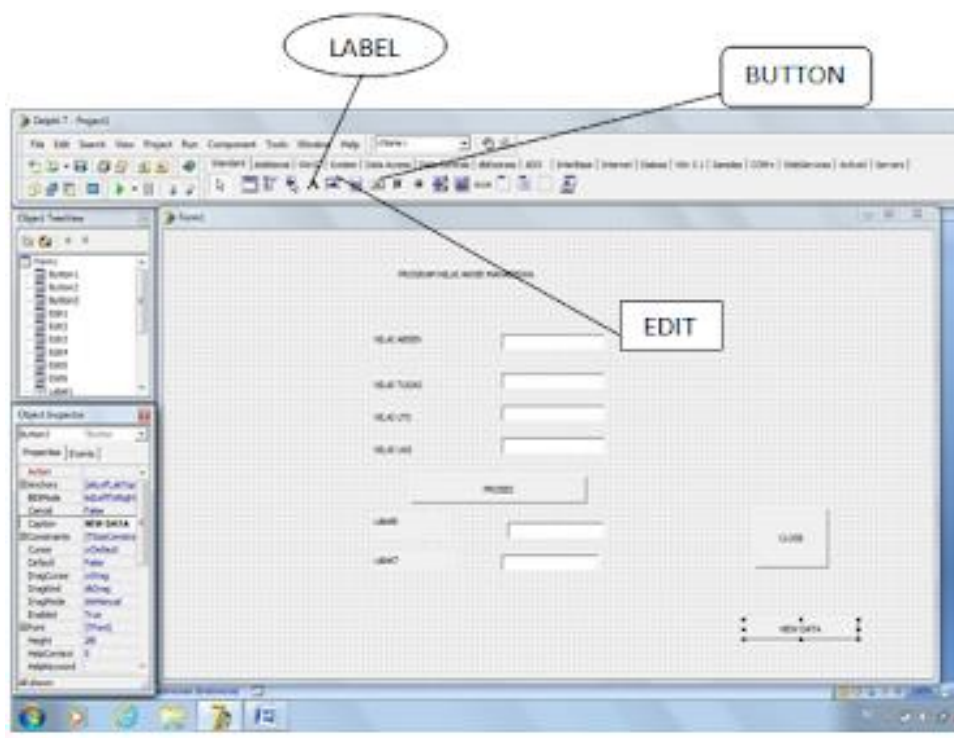

$\aleph \quad$ Kemudian buatla nama nam program

yang hendak dijalankan baik dari label,Edit maupun tabel

$\aleph \quad$ Catatan kecil: Untuk mengubah nama Label,Button maupun edit diambil dari Caption pada objeck Inspecktor $\aleph$

Untuk mengubah ukuran,warna, jenis 
huruf maupun ketebalannya dapat dilihat dari Objeck Inspecktor pada property ( font ), tetapi terlebih dahulu aktifkan Edit,Label maupun button yang hendak diubah.

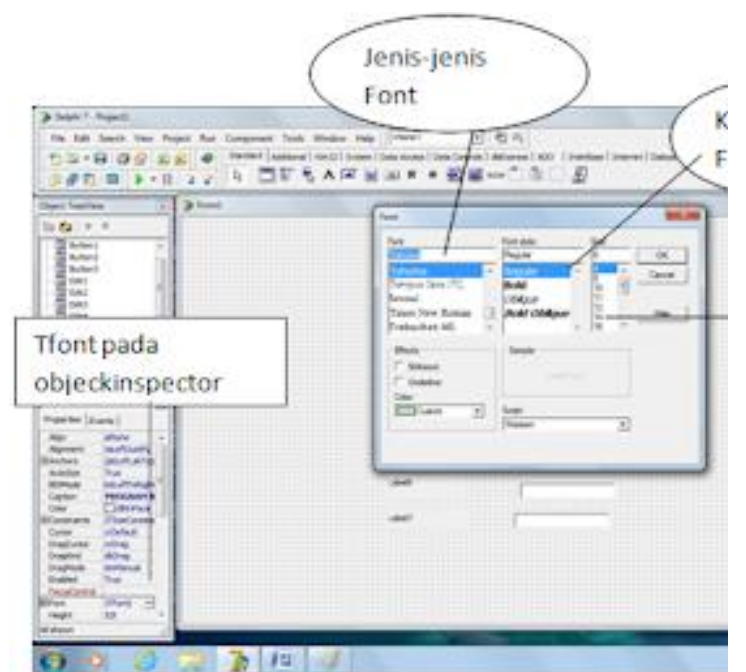

* Setelah kita menyusun kata perkata yang ada pada label,Edit maupun button,kemudian kita klik button proses. Button proses adalah otak dari setiap kode program yang hendak dijalankan.Berikut tampilan awal yang muncul (klik button proses 2kali).

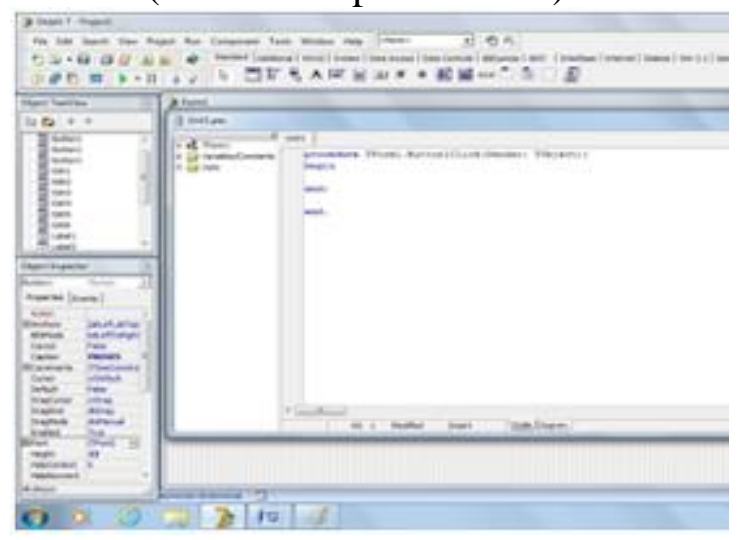

Pada button proses masukkan data yang akan diimput maupun data yang akan di proses

Contoh:
Var

nabsen,ntugas,nuts,nuas:integer;

nhuruf:char;

nakhir:real;

begin

nabsen:=strtoint(edit1.text);

ntugas:=strtoint(edit2.text);

nuts:=strtoint(edit3.text);

nuas:=strtoint(edit4.text);

begin

if (nakhir > = 80) and (nakhir $<=100$ )

then

nhuruf:='A'

else

if (nakhir > = 70) and (nakhir <= 89)

then

nhuruf:='B'

else

if (nakhir > =60) and (nakhir $<=69$ )

then

nhuruf:=' $C$ '

else

if (nakhir > = 50) and (nakhir <=59)

then

nhuruf:='D'

else

if (nakhir > = 40) and (nakhir <=49)

then

nhuruf:='E'

else

if (nakhir > =0) and (nakhir <=39)

then

nhuruf:='F'

end;

edit5.text:=nhuruf;

edit6.text:=floattostr(nakhir);

end;

end.

$\aleph \quad$ maka akan tampak seperti yang ada pada gambar dibawah ini; 


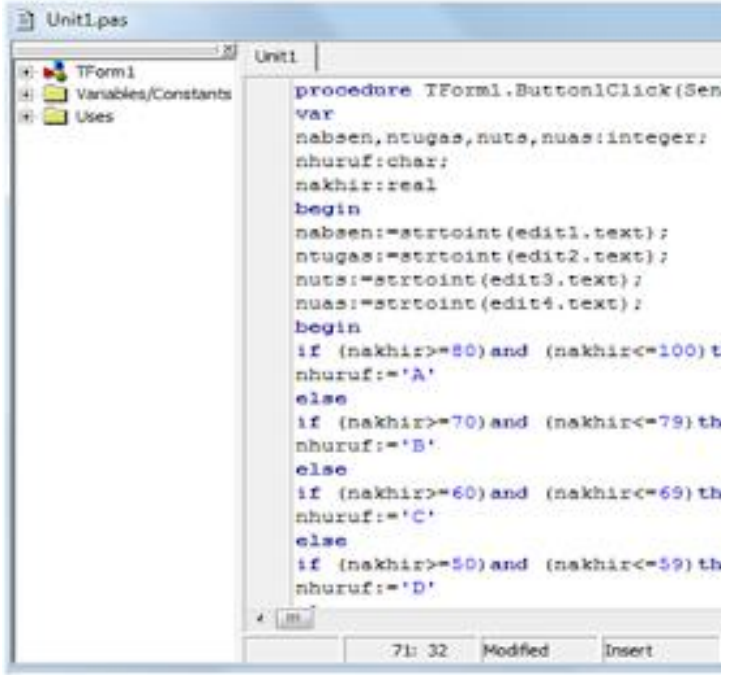

$\aleph \quad$ Untuk mengaktifkan Button Close (klik Button close dua kali) masukkan kode programnya.

Contoh:

Procedure......

Begin

Close;

End;

End.

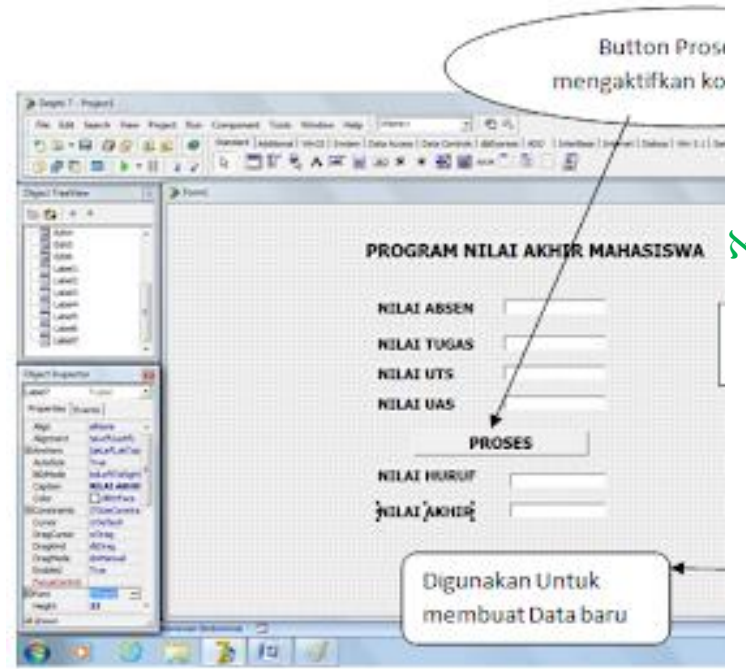

$\aleph \quad$ Berikut tampilan yang akan tampak pada Button New data

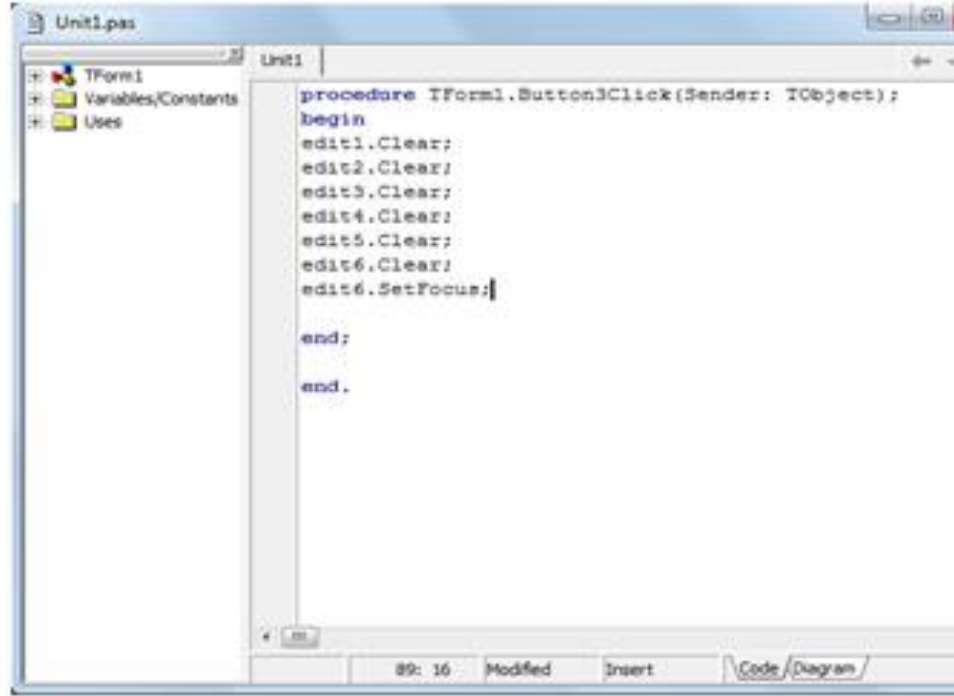

$\aleph \quad$ Setelah listing program selasai maka program dapat di jalankan (RUN) dan inputlah nilai absen,tugas,uts dan uas kemudian klik button Proses maka akan tampak tampilan sebagai berikut:

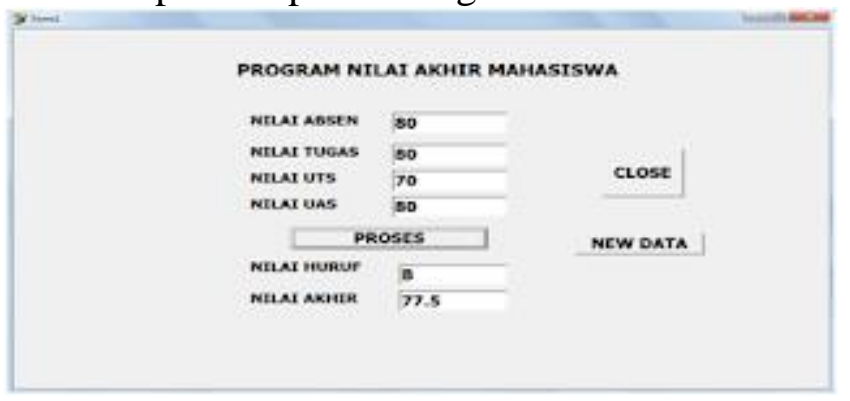

Jika anda mengklik Button New Data maka data yang anda imput akan di hapus guna untuk mengimput data baru. Berikut tampilan interfacenya;

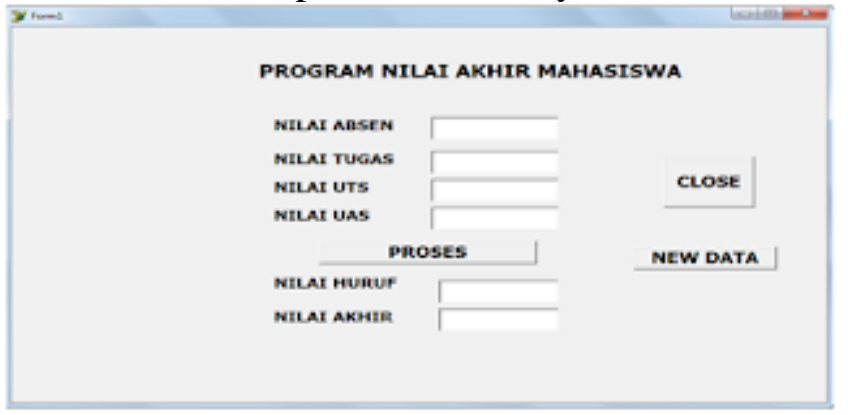




\section{CONCLUSION}

Kesimpulan dari materi ini:

Borland Delphi 7 adalah bahasa pemrograman yang bekerja pada lingkup sistem operasi windows, dan merupakan salah satu program yang berorientasi object ( OOP ). kemampuanya dapat dipakai untuk merancang program aplikasi yang berpenampilan seperti program aplikasi lainya yang berbasis Windows. Kemampuan Borland Delphi 7 secara umum adalah menyediakan komponen komponen yang memungkinkan anda membuat program aplikasi yang sesuai dengan tampilan dan cara kerja windows, diperkuat dengan bahasa pemrograman tersetruktur yang sangat handal, yaitu bahasa pemrograman Object Pascal yang sangat terkenal. Khusus untuk pemrograman database Borland Delphi 7 menyediakan fasilitas object yang sangat kuat dan lengkap.

\section{DISCUSSION}

Hasil diskusi dari materi ini adalah:

Kemampuan dalam Borland Delphi 7 secara umum adalah menyediakan komponen komponen yang memungkinkan anda membuat program aplikasi yang sesuai dengan tampilan dan cara kerja windows, diperkuat dengan bahasa pemrograman tersetruktur yang sangat handal, yaitu bahasa pemrograman Object Pascal yang sangat terkenal. Khusus untuk pemrograman database Borland Delphi 7 menyediakan fasilitas object yang sangat kuat dan lengkap.

\section{E. REFERENCE}

[1] O. M. Febriani and A. S. Putra, "Sistem Informasi Monitoring Inventori Barang Pada Balai Riset Standardisasi Industri Bandar Lampung," J. Inform., vol. 13, no. 1, pp. 90-98, 2014.

[2] A. S. Putra, "Paperplain: Execution Fundamental Create Application With Borland Delphi 7.0 University Of Mitra Indonesia," 2018.

[3] A. S. Putra, "2018 Artikel Struktur Data, Audit Dan Jaringan Komputer," 2018.

[4] A. S. Putra, "ALIAS MANAGER USED IN DATABASE DESKTOP STUDI CASE DB DEMOS."

[5] A. S. Putra, "COMPREHENSIVE SET OF PROFESSIONAL FOR DISTRIBUTE COMPUTING."

[6] A. S. Putra, "DATA ORIENTED RECOGNITION IN BORLAND DELPHI 7.0."

[7] A. S. Putra, "EMBARCADERO DELPHI XE 2 IN GPUPOWERED FIREMONKEY APPLICATION."

[8] A. S. Putra, "HAK ATAS KEKAYAAN INTELEKTUAL DALAM DUNIA TEKNOLOGY BERBASIS REVOLUSI INDUSTRI 4.0."

[9] A. S. Putra, "IMPLEMENTASI PERATURAN PERUNDANGAN UU. NO 31 TAHUN 2000 TENTANG DESAIN INDUSTRI BERBASIS INFORMATION TECHNOLOGY." 
$\begin{array}{llr}\text { [10] } & \begin{array}{l}\text { A. } \\ \text { "IMPLEMENTATION }\end{array} & \text { Putra, } \\ & \text { OFARADOX DBASE." } & \end{array}$

[11] A.

A. S. Putra,

"IMPLEMENTATION OF

TRADE SECRET CASE

STUDY SAMSUNG MOBILE PHONE."

[12] A.

S. Putra,

"IMPLEMENTATION

PATENT FOR APPLICATION

WEB BASED CASE STUDI

WWW. PUBLIKLAMPUNG. COM."

[13] A.

"IMPLEMENTATION

SYSTEM FIRST TO INVENT IN DIGITALLY INDUSTRY."

[14] A. S. Putra, "MANUAL REPORT \& INTEGRATED DEVELOPMENT

ENVIRONMENT BORLAND DELPHI 7.0."

[15] A. S. Putra, "PATENT AS RELEVAN SUPPORT RESEARCH."

[16] A. S. Putra, "PATENT FOR RESEARCH STUDY CASE OF APPLE. Inc."

[17] A. S. Putra, "PATENT PROTECTION FOR APPLICATION INVENT."

[18] A. S. Putra, "QUICK REPORT IN PROGRAMMING."

[19] A. S. Putra, "REVIEW CIRCUIT LAYOUT COMPONENT

REQUIREMENT ON ASUS NOTEBOOK."

[20] A. S. Putra, "REVIEW TRADEMARK PATENT FOR INDUSTRIAL TECHNOLOGY BASED 4.0."

[21] A. S. Putra, "TOOLBAR
COMPONENT PALLETTE IN

OBJECT

ORIENTED

PROGRAMMING."

[22] A. S. Putra, "WORKING DIRECTORY SET FOR PARADOX 7."

[23] A. S. Putra, "ZQUERY CONNECTION

IMPLEMENTED

PROGRAMMING STUDI CASE PT. BANK BCA Tbk."

[24] A. S. Putra, D. R. Aryanti, and I. Hartati, "Metode SAW (Simple Additive Weighting) sebagai Sistem Pendukung Keputusan Guru Berprestasi (Studi Kasus: SMK Global Surya)," in Prosiding Seminar Nasional Darmajaya, 2018, vol. 1, no. 1, pp. 85-97.

[25] A. S. Putra and O. M. Febriani, "Knowledge Management Online Application in PDAM Lampung Province," in Prosiding International conference on Information Technology and Business (ICITB), 2018, pp. 181-187.

[26] A. S. Putra, O. M. Febriani, and B. Bachry, "Implementasi Genetic Fuzzy System Untuk Mengidentifikasi Hasil Curian Kendaraan Bermotor Di Polda Lampung," SIMADA (Jurnal Sist. Inf. dan Manaj. Basis Data), vol. 1, no. 1, pp. 21-30, 2018.

[27] A. S. Putra, H. Sukri, and K. Zuhri, "Sistem Monitoring Realtime Jaringan Irigasi Desa (JIDES) Dengan Konsep Jaringan Sensor Nirkabel," IJEIS (Indonesian J. Electron. Instrum. Syst., vol. 8, no. 2, pp. 221-232. 
Fakultas Komputer

Lia Aulina

UAS - 88675543

[28] D. P. Sari, O. M. Febriani, and A. S. Putra, "Perancangan Sistem Informasi SDM Berprestasi pada SD Global Surya," in Prosiding Seminar Nasional Darmajaya, 2018, vol. 1, no. 1, pp. 289-294. 